Review article

\title{
Birleşmiş Milletler’in Engelsiz Yaşamı Oluşturma Çabaları Doğrultusunda Sosyal Koruma Politikalarının Değerlendirilmesi ${ }^{1}$ Evaluation of the United Nations' Social Protection Policies and Their Efforts to Generate Barrier-Free Living
}

\author{
Ruhal Samanlı (1) " \\ Department of Labor Economics and Industrial Relations, Faculty of Economics and Administrative Sciences, Çankırı Karatekin University, Çankırı, \\ Turkey
}

\begin{abstract}
Özet
Her toplumda fiziksel, bilişsel, duyusal ve sosyal bakımdan özel gereksinimi olan insanlar bulunur. Bu insanların yaşamlarını kolaylaştırmak amacını taşıyan çalışmalar da engelsiz yaşamı sağlama çalışmalarıdır. Engelsiz yaşamın oluşturulması ve devamlılığıın sağlanması toplum bütünlüğüne etki edebilecek sosyal koruma politikalarını gerektirir. Açıkçası, herhangi bir bölgede ortaya çıkan bir sorunun büyük kitleleri etkileyebilecek güce sahip olması nedeniyle uluslararası alanda etkili çalışmaların yürütülmesi gereklidir. Bu bağlamda küçük bir kitleyi etkileyerek ortaya çıkan ve büyük kitleleri etkileme ihtimali yüksek sorunlarla ilgilenen uluslararası örgütler, uluslararası entegrasyonu yükseltecek çalışmalara ağırlık vermektedir. Uluslararası arenada etki gücü yüksek bir örgüt olan Birleşmiş Milletlerin engellilere yönelik çalışmaları, uluslararası alanda entegrasyonu sağlamak başta olmak üzere diğer oluşturulmak istenen standartlara öncülük etmektedir. Birleşmiş Milletlerin çabaları ile engelsiz yaşamı sağlama çalışmaları sosyal entegrasyonu geliştirme fikri doğrultusunda ilerletilmektedir. Bu çalışmada Birleşmiş Milletlerin sosyal koruma politikaları ile engelsiz yaşamı sağlayabilme durumu değerlendirilerek, Birleşmiş Milletlerin engelsiz yaşamı sağlama potansiyeli konusunda bir tartışma zemini yaratmak planlanmaktadır. Birleşmiş Milletlerin engellilere yönelik düzenlemeleri engelsiz yaşamı sağlama amacına uygun şekilde çalıştığına işaret etmektedir. Ancak farklı etkileyicilerden kaynaklanan sorunlar engelsiz yaşamın oluşturulmasında ve sürdürülebilirliğinde endişelere neden olmaktadır. Engelsiz yaşama ilişkin sorunların tamamen yok olmaması tartışma zemininin yaratılmasında ve devam etmesinde etkilidir. Birleşmiş Milletlerin toplum bütünlüğünü destekleme sorumluluğunu ortaya koyması bakımından önemli olan bu çalışma, teorik olarak ele alınacaktır. Çalışma, engelsiz yaşama ilişkin literatürün taranması ve ilgili Birleşmiş Milletler belgelerinin incelenmesi bağlamında tümden gelim metodu ile hazırlanacaktır. Açıkça ifade etmek gerekirse, Birleşmiş Milletlerin engelsiz yaşamı sağlama performansının değerlendirilmesi amacı ile hazırlanan çalışmada, kişilerin önyargılarının etkisinin ve ülkelerin iç yapısı ile ilişkili konuların Birleşmiş Milletlerin oluşturmak istediği standartları kesintiye uğrattığı sonucuna erişilmiştir.
\end{abstract}

Anahtar Kelimeler: Sosyal Politika, Engelliler, Engelsiz Yaşam, Sosyal Koruma, Birleşmiş Milletler.

\footnotetext{
${ }^{1}$ This study is an extended version of the paper presented orally and published in the full text booklet at the TAEM International Congress of Social Policy 2019 on 20 June 2019.

\section{* Corresponding author:}

Samanlı, Department of Labor Economics and Industrial Relations, Faculty of Economics and Administrative Sciences, Çankırı Karatekin University, Çankırı, Turkey.

Email:ruhalsmnl7@gmail.com
} 


\begin{abstract}
People who need special physical, cognitive, sensory, and social assistance exist in each society. Actions to facilitate these people's lives can provide them with barrier-free living. Social protection policies that can affect the whole of society are required to constitute and maintain barrier-free living. Moreover, studies should be conducted that would be effective internationally because a problem in any area may have the power to influence large masses of people. Accordingly, international organizations, which deal with problems that emerge from a smaller population but have the potential of affecting larger populations, prioritize studies that can promote international integration. Because it is an organization with a great impact internationally, the United Nations has conducted studies of people with disabilities that would lead to international integration of the desired standards. In parallel with the great efforts of the United Nations, studies to provide barrier-free living are carried out with the intention of promoting social integration. This study evaluated the efforts of the United Nations to provide barrier-free living, along with their social protection policies, and generated grounds for discussion about the potential of the United Nations to provide barrier-free living. The United Nations' regulations concerning people with disabilities indicate that they work in line with their aims to provide barrier-free living. However, problems emerging from various factors cause concerns about bringing about and maintaining barrierfree living. The ongoing problems related to barrier-free living can create and maintain grounds for discussion. This study, which is important for the United Nations to demonstrate its responsibility to support the integrity of society, will theoretically be addressed. The study will be prepared by whole deductive method in the context of scanning the literature on barrier-free living and examining the relevant United Nations documents. To be clear, the study, which was prepared to evaluate the performance of the United Nations in ensuring barrier-free living, concluded that the impact of people's prejudices and the issues associated with the internal structure of countries disrupted the standards that the United Nations wanted to establish.
\end{abstract}

Keywords: Social Policy, People with Disabilities, Barrier-free Living, Social Protection, United Nations

Received: 09 August 2021 * Accepted: 03 September 2021 * DOI: https://doi.org/10.29329/ijiasos.2021.368.2

\title{
GíRiș
}

Engelli olarak ifade edilen kişiler, doğum öncesinde veya doğum esnasında ortaya çıkan faktörler ile büyüme ve yetişme esnasında ortaya çıkan bir kaza veya bir hastalıkla bağlantılı durumun özneleridir. Farklı hikâyelere sahip bu insanların tek ortak noktası, engelli olarak bir grubun içerisine dâhil edilmek ve yaşamın doğal akışı esnasında birtakım zorluklarla karşılaş̧maktır. Bu ortak nokta neticesinde engelliler, genel olarak toplumdan izole olarak yaşayan, tek başına gereksinimlerini karşılayamayan, risklere açık olan ve korunması gereken kişiler haline gelmektedir.

Engelliler, sosyal devlet anlayışı kapsamında gerçekleştirilen sosyal koruma politikalarının gündeminde yer almaktadır. Sosyal hayata uyum sağlama çalışmalarının özneleri olan engellilerin yaşamlarını kolaylaştırmak da sosyal koruma aktörlerinin sorumluluk alanına girmektedir. Öncelikle devlet, STK'lar ve aileler, engelli bireylerin hayatını kolaylaştırma çabasındadır. Bu bağlamda öne sürülen "engelsiz yaşam" fikri anlamlıdır. Fiziksel, bilişsel, duyusal ve sosyal anlamda engelsiz yaşam, öncelikle özel gereksinimi olan insanların hayatını kolaylaştırmaya yönelik çalışmaları içermektedir. Açıkça ifade etmek gerekirse, doğal yaşam döngüsü içerisinde engellerden yoksun ve erişilebilir bir 
yaşam tüm insanların doğal hakları arasında yer alsa da engelliler için kritik öneme sahiptir. $\mathrm{Bu}$ doğrultuda ekonomik ve sosyal anlamda topluma yük gibi görülen engellilerin, yaşamın bir parçası olduğu ve birtakım haklara sahip olduğu unutulmamalıdır. Bu düşünce tarzı sosyal uyumu sağlama açısından da gereklidir. Bu konuda öncü olarak tavsiyeler vermek ve standartlar oluşturmak amacında olan ulusal birimler olduğu gibi uluslararası birimler de mevcuttur.

Uluslararası anlamda standartlar oluşturmak noktasında Birleşmiş Milletlerin (BM) tutumu yadsınamayacak derecede önemlidir. BM'nin kurulduğu tarihten itibaren yarım asırdan fazla bir süre geçmiştir. $\mathrm{Bu}$ süre zarfında $\mathrm{BM}$ tarafından engelsiz yaşam için azımsanmayacak sayıda çalışma yapılmıştır. Ancak engelsiz yaşamı sağlama açısından bunların etkili olup olmadığının ayrıca değerlendirilmesi gerekmektedir.

$\mathrm{Bu}$ çerçevede çalışmamızda engellilerin yaşadıkları zorluklarla engelsiz yaşamın önemi ve gerekliliği ortaya konarak, uluslararası alanda etkili olan BM'nin engelsiz yaşamı oluşturma amacı ile paralel çalışmaları ele alınacaktır. Bu bağlamda BM'nin engelsiz yaşamı sağlama potansiyeli de değerlendirilmiş olacaktır. Açıkçası, bu çalışmanın dayanağı olan temel iddia 2000 sonrasında BM'nin gündeminde önemli yer edinen sosyal koruma politikaları ile engelsiz yaşamın sağlanabileceği ve birçok olumsuzluğa maruz kalabilen engellilerin yaşamının iyileştirilebileceğidir. Çalışmada literatür taraması ile ikincil kaynaklardan, raporlardan, sözleşmelerden elde edilen veriler nitel analiz yöntemlerinden olan ve huni metodu olarak da isimlendirilen tümden gelim metoduna göre analiz edilecektir.

\section{Engellilik Hali ve Bağlantılı Zorlukları}

Genel olarak doğum öncesi, doğum anı veya doğum sonrasının herhangi birinde bazı etmenlerden dolayı zedelenen duyu organlarının işlevleri azalır veya yok olur (Çitil- Üçüncü, 2018: 235). Bu durumda işlevsel sorunlardan kaynaklı olarak bireysel beceriler ya tamamen yok olur ya da kısmen azalır. Bireysel becerileri azalan veya tamamen yok olan insanları ifade ederken engelli kavramı kullanılmaktadır (Genç-Çat,2013:365). Engelli olarak ifade edilenlerin engelli olarak ifade edilmeyenlerle eşit şartlar altında sosyal hayata katılmasına mâni olan hale de engellilik hali denmektedir (Azarkan- Benzer, 2018:6).

Engelliliğin, sakat veya özürlü olma tabirlerinden farklı bir yapısı vardır. Kişinin var olan durumunu ifade etmek için yakın zamana değin kullanılan sakat veya özürlü kelimeleri hukuki ve sosyal açıdan yetersiz kalmaktadır. Bireyi etiketlemek ve bireyin içinden gelen bir durum konusunda yetersizlik algısı yaratmak için kullanılan sakat veya özürlü kelimesinin yerine, çevresel faktörlerin, toplumsal algının ve bireyin dışından kaynaklanan durumların daha rahat ifade edilebileceği engelli kelimesi kullanılmaktadır. Holistik bakış açısının ürünü sayılabilen engelli kelimesi ile hem herhangi bir etmenden kaynaklı olarak bazı işlevlerini kaybeden insanlar hem de çevresel ve toplumsal bariyerler ifade edilebilmektedir (Çitil- Üçüncü,2018:236; Titchkosky,2000:198). 
Engellilik, fiziksel, duyusal, ruhsal ve zihinsel açıdan yaşamın sınırlandırılmasıdır. BM Engellilik İstatistikleri Veri Tabanı belgelerine göre engellilik, vücut fonksiyonlarının azalması veya sınırlanması ile görme, duyma, konuşma, anlama, yürüme konusunda sorunların yaşanmasıdır. Dünya Bankasına göre engellilik, zihinsel, duyusal, psikolojik zayıflıkları içeren geniş bir kavramdır. Dünya Sağlık Örgütü’nün 2011 raporuna göre engellilik; dinamik, karmaşık, uzun zamandır tartışılan ve çok boyutlu bir konudur. Genel olarak tüm vücut fonksiyonlarının azalması veya sınırlanması ile ilişkili olarak aktiviteyi azaltan şemsiye bir kavram olan engellilik, esnek bir yapıya sahiptir (WHO, 2011:27; World Bank Group,2018:1; Haveman-Wolfe,1990:34).

Engellilik, bazen bir kaza sonucu ortaya çıkarken, bazen de sonucu önceden tahmin edilebilen bir hastalıktan kaynaklanmaktadır. Tıbbi açıdan bakılacak olursa, fiziksel ve zihinsel engellilik hali 45 yaş sonrasında ortaya çıkan alzheimer, görme ve işitme bozukluğu, osteoporoz, artrit, diyabet, yaralanma yaşa bağlı olarak neuropsychiatric yapının zarar görmesi gibi farklı hastalıklarla ilişkilendirilmektedir. Ayrıca sigara ve alkol tüketiminin fazla olmasının da engelliliğe neden olduğu belirtilmektedir. Afrika, Amerika, Batı Avrupa ve Kuzey Amerika'da alkole bağlı engelliliğin yüksek olduğu ifade edilmektedir (WHO, 2004:29-113).

Engelliler, genel olarak engeli olmayanların önyargılarına maruz kalmaktadır. Engeli olmayanların olumsuz düşüncelerinin olumsuz tutumlara dönüşmesinin sonucunda beceriksiz, yeteneksiz gibi kötü sıfatlar ile anılabilen engelliler görmezden gelinmektedir veya toplumdan dışlanmaktadır. Negatif tutumun şiddetli bir şekilde ayrımcı uygulamalara dönüşmesiyle engellilerin, işyerinde, toplu taşımada, sokakta, parkta, okulda karşılaşılan engellerle yaşam alanları sınırlandırılmaktadır (Lee, 2003:185; Neufeldt,1995:177; Powell- Lovelock, 1997:580).

Bir taraftan, engellilerin çevresel bariyerler olarak tabir edilebilen engeller ile yaşam alanları sınırlandırılmaktadır. Eşit yaşama hakkına mâni olan bariyerler gerçekte insanın insana uyguladığı şiddetin şekil değiştirmiş halidir. Sınırlı bakış açısı ile tasarlanan mahalleler ve kentler ihtiyaca cevap vermediği gibi engellilerin yaşamının devamlılı̆̆ını da tehdit etmektedir. Dar geçitler, dik merdivenler, ağır kapılar, asansörsüz binalar, tehlike içeren yüksek ve camlı resepsiyon masaları, engebeli ve aşılması zor yollar, kullanımı zor tuvaletler ve vestiyerler ile engellilerin kreşlere, parklara, buluşma yerlerine, spor alanlarına, atölyelere, tiyatro ve konser salonlarına, okullara, tiyatrolara, kütüphanelere erişimi olmamaktadır ya da kısitlanmaktadır (Gorz, 1999:101-102; Sendi- Kefo, 2009:135).

Diğer taraftan engellilerin en çok zaman geçirdiği alanlar olan evler, birçok konuda engellinin hayatını sınırlandırmaktadır. Perdenin, klimanın, ocağın, kapının, ışıkların açılıp kapatılması, çöplerin atılması, yemeklerin pişirilmesi veya 1sıtılması, ütünün yapılması, çamaşırın ve bulaşığın yıkanması, çiçeklerin sulanması gibi basit denebilecek faaliyetlerin yapılması engelli bireyler için kolay olmamaktadır. Bu açıdan engelliler kendilerine destek olacak birine ihtiyaç duymaktadır. Aksi takdirde tek başına yaşayan engellinin ev işlerini yapması mümkün olmadığından ya da çok zor olduğundan en 
çok zaman geçirilen evde yaşam daha da zorlaşmaktadır (WHO, 2011:27; Bricout-vd., 2004:58; Neufeldt, 1995:176; Soriano vd., 2003:392). Brkic vd., tarafindan 2012 y1lında Sirbistan'da yapılan ve 586 zihinsel engelli çocuğu ve genci kapsayan bir ankete göre ev içerisinde uzun zaman geçiren engelliler yapısal ve fonksiyonel yetersizliklerle bağlantılı pek çok sıkıntı yaşamaktadır (Brkic vd.,2012).

Engeli olmayanların empati yeteneğinden yoksun olması sorunların ana nedenlerindendir. Engellilerin karşılaştığı en büyük engellerden biri de gelişim için inkâr edilemeyecek derecede önemli olan eğitim planlarının özensiz bir şekilde hazırlanmasıdır. Özellikle engeli olan bireyin yeteneğini geliştirmek ve toplum içerisinde yer almasını sağlamaya yönelik planların olmaması büyük eksikliktir (Filmer, 2008:15; Haveman-Wolfe, 1990:43-49). Engelli çocukların pedagojik yapısı ve değerlendirme ölçütleri düşünülmeden hazırlanan müfredatlar, çalışanların tutumu ve tesisin donanımının uygun olmaması gibi sorunlar engelli eğitiminin kalitesine gölge düşürmektedir. Engelli eğitimine yapılan eleştirilerden bir tanesi geleceğe yönelik olmaması; diğeri ise eğitim tesislerinin engelli kişilerin gelişimi için etkisiz olmasıdır. Yapılan araştırmalar göstermektedir ki, yetişkin engellilerin yüzde 25'inin bir becerisi bulunmamaktadır. Bu durumdan etkilenenlerin büyük bir kısmı ise öğrenme güçlüğü çeken zihinsel engellilerdir. Eğitim ile istihdam arasındaki kuvvetli bağ düşünülürse, özenle hazırlanmış eğitim planlarının engelliler üzerinde olumlu katkıları olabilecektir (Filmer, 2008:155-156; Oliver- Barnes, 2010:550-555).

Engellilerin rehabilitasyonunda önemli rolü olan sağlık, birtakım unsurları barındırmaktadır. Sağlıkla ilişkili en gerekli unsur finansal destektir. 2005 küresel araştırma sonuçlarına göre gelişmekte olan 114 ülkenin 37 tanesi engellilere yönelik rehabilitasyon çalışmalarına bütçe ayırmamaktadır. 56 ülke de engelli sağlık hizmetini eski bilgilerle yapmaktadır ve modern bilgileri kullanmamaktadır. Sağlık alt yapısının, teknolojik destek unsurlarının, planlamanın eksikliği, kaynak yetersizliği ve uzman sayısının yeterli sayıda olmaması nedeniyle sağlık hizmetleri yapılamamaktadır veya eksik kalmaktadır (Dünya Engellilik Raporu, 2011).

Diğer taraftan, ekonomi açısından bakılacak olursa, çalışma yetisinin büyük bir kısmını kaybeden ve çok az gelirle geçinmesi beklenen engellilerin yoksullukla ve bağlantılı sorunlarla karşılaşma ihtimali yüksektir. Engellilerin, engeli olmayanlara göre üç kat daha fazla işsiz kaldığı tahmin edilmektedir. Bunun bir sonucu olarak engelliler, en temel ihtiyaçlarını karşılamakta zorlandığı gibi eğitim ve sağlık imkânlarından da yeterli şekilde istifade edememektedir (Edwards, 2001:273-278).

İstihdam açısından bakılacak olursa, istihdamda yer alabilen engelliler de işe alım sürecinden başlayarak terfi ve ücret konusunda ayrımcılığa maruz kalmaktadır. 1980’lerin ortasından bu yana işgücünün vasıf düzeyinin artırılması, engellilerin vasıfsız kalmasına neden olmaktadır. Bu durumda engelliler ya işsiz kalmaktadır ya da kötü koşullarda engelli olmayanların aldığı gelirin yaklaşık yarısını alarak çalışmaktadır. Liberal ekonomik sistem içerisinde yer alan engelliler, sosyal hareketliliğin bir 
parçası olarak ezilseler de gelecek planları için vazgeçilemeyenler grubunun içerisindedirler (Brzuzy,1999:5; Barnes-Mercer, 2005:534; Lee, 2003,185; Neufeldt, 1995:177; Powell- Lovelock, 1997:580).

Fiziksel, zihinsel, ruhsal, duyusal açıdan birçok konuda engeller ile karşılaşılmaktadır. Bu açıdan engellerle karşılaşan ve yaşam alanları sınırlanan engellilerin, yaşam alanlarının sınırlandırılmadığı ya da daha az sınırlandırıldığı alanlarda varlıklarını devam ettirmeleri gerekmektedir. Dünya Bankası, engelli olarak kabul edilenlerin büyük bir kısmının gelişmiş ülkelerde yaşadığını iddia etmektedir. BM Kalkınma Programı da engellilerin \%80'inin gelişmiş ülkelerde yaşadığını vurgulamaktadır. $\mathrm{Bu}$ durumun gelişmiş ülkelerde yaşamın daha kolay olacağı, şiddetin ve benzeri olumsuzlukların olmayacağı inancı ile ilgili olduğu tahmin edilmektedir (UNDP, 2021). Görme engellilere yönelik ilk kütüphanenin gelişmiş ülkeler arasında yer alan Hollanda' da kurulması ve zamanla Hollanda'nın diğer şehirlerinde yer alan kütüphanelerde de görme engellilere yönelik bölümlerin oluşturulması ve görme engellilere yönelik ilk derginin 1957 yılında Hollanda'da yayın hayatına adım atması, Portekiz ve Finlandiya'da ülke diline uygun işaret dili sisteminin oluşturulması, İsveç’te yabancı dil eğitimi kapsamında işaret dili eğitiminin verilmesi ve İngiltere televizyon programlarında işaret diline yer verilmesi engellilerin gelişmiş ülkelerde daha iyi imkânlara sahip olduğu düşüncesini desteklemektedir (Tellioğlu,2019:168).

\section{Bileşenleri ile Engelsiz Yaşam ve Sosyal Koruma Olgusu}

Engelliler, II. Dünya Savaşından sonra engelli sayısının toplam nüfus içerisinde yüksek olması ve işgücü açığının ortaya çıkması ile dikkat çekmiştir. Bu bağlamda engellilerin rehabilitasyonu, istihdamda yer almaları ve toplumla kaynaştırılmaları gerektiği öne sürülmüştür. Bu düşünceler engelli kişiyi yetersizlikle suçlayan, toplumun katı ve değiştirilemez olduğunu belirten ve engellinin topluma uyum sağlaması gerektiğini öne süren tıbbi medikal modele karşı olan ve 20. yüzyılın ikinci yarısı ile birlikte gündemdeki yerini alan sosyal modelin benimsenmesiyle alakalıdır. İnsancıl bir yapıya sahip olduğu belirtilen sosyal modele göre engellilik, engeli olmayan insanların yarattığı bir durumdur. Engeli olmayan insanların ayrımcı ve etiketlemeye yönelik tutumlarının neticesinde yasalar, politikalar ve kurumsallaşmış alışkanlıklar engellere neden olmaktadır (Çitil- Üçüncü, 2018:238- 239; Kara, 2016:253-254; Friedman, 2020:596).

En büyük engellerden biri de şiddettir. Şiddetin farklı türlerinin mağduru olma ihtimali yüksek olan engelliler, yasalar tarafından yeterince korunamadığında öncelikle birinci derece yakınlarından daha sonra da diğer insanlardan şiddet görebilmektedir. Psikolojik ve cinsel şiddet mağduru olma ihtimali yüksek olan engelliler sömürme, yıpratma ve taciz vakaları ile karşılaşabilmektedir. Genel olarak beş engelliden birinin dövüldüğü ve sözel şiddet mağduru olduğu belirtilmektedir. Engelli çocukların engelli olmayan çocuklara göre 4 kat daha fazla şiddet gördüğü iddia edilmektedir ve korunmasız oldukları belirtilmektedir. Medikal araştırma dergisi Lancet'e göre engelli çocukların 
herhangi bir şiddetin kurbanı olma ihtimali engeli olmayan çocuklara göre 3,7 kat daha fazladır (Hughes, 2012:9-10; Habib, 1995: 51; WHO, 2011: 85; UN Report, 2019:16).

Engelli kadınlar engelli olmayan kadın akranlarına göre daha fazla şiddete maruz kalmaktadır. Malecki ve arkadaşları tarafından yapılan araştırmada da engelli kadınların daha fazla şiddet gördüğü öne sürülmektedir. Kanada'da kadınlar tarafından 1985 yılında kurulan ve kadınlara yönelik çalışmalara öncelik veren DAWN Canada (Disabled Women's Network for Canada), engelli kadınların diğer kadınlara nazaran daha fazla şiddete uğradığını ve bu duruma katlanamayan kadınların da intihar ettiğini iddia etmektedir (Malecki vd., 2020:127; DAWN CANADA, 24 Mart 2021).

Engellilerin yaşadığı olumsuz durumlar ve savunmasız olmaları uluslararası alanda etkili kuruluşların dikkatini çekmektedir. Dünya Sağlık Örgütü (DSÖ), engellilerin şiddete maruz kaldığını belirterek acil eyleme gereksinim olduğunu öne sürmektedir. DSÖ Şiddet ve Yaralanmayı Önleme Engellilik Departmanı Başkanı Etienne Kung da özellikle engelli çocukların korunmaya ihtiyaç duyduğunu ifade etmiştir (Hughes, 2012:9-10; Habib, 1995:51; WHO, 2011: 85; UN Report, 2019:16).

Sürdürülebilir sosyal yaşam için engellerin yok edilmesi gerekmektedir. Engelleri yok edebilme de "sosyal koruma" ile mümkündür. Sosyal koruma ile engelli bakımını üstlenenlerin bilinçsizliği, engellinin sağlık ve eğitim imkânlarının sınırlılığı, gelir noksanlığı veya eksikliği kapsamındaki sorunlar giderilebilir, fırsatlar yaratılabilir ve sosyal yaşam iyileştirilebilir. Bu bağlamda sosyal hayata katılımı artıracak kaynaştırma metodu da engellilerin sorunlarını çözebilmek adına faydalı olacaktır (Brkic vd., 2012:248).

Engelsiz yaşamı mümkün kılmaktan daha önemlisi de sürdürülebilir kılmaktır. Bu bağlamda sosyal politikanın sadece çalışan ve çalıştıran arasındaki ilişkiyi ele alan dar halinden ziyade tüm insanların haklarını ve gereksinimlerini ele alan geniş halinin önemsenmesi gerekmektedir. Sosyal devlet anlayışının gerekliliği ile ortaya çıkan sosyal politika ve bağlantılı olarak sosyal koruma çalışmaları ahlaki, hukuki ve vicdani tutumun bir yansıması olarak hibrit bir şekilde değerlendirilmektedir. Bu bağlamda insan hak ve onurunu korumayı pek çok amaçtan daha fazla önemseyen sosyal korumanın yaşamın her noktasına sirayet ettirilmesi ile yaşam standartlarının düşüşü de engellenebilecektir (UN Report, 2017:5; Kapar, 2003:49).

Sosyal koruma ile risklere karşı durabilmek mümkündür. Risklerin birçoğunun gelir azlığı veya noksanlığı ile ilişkisi bulunur. Gelir güvencesinin olmaması veya eksikliği geleneksel yöntemlerden biri olan aile veya akraba dayanışmasını gündeme getirirken, resmi nitelikli sosyal yardımlar da ülkelerin gelişmişliği ölçüsünde gündemdeki yerini alır. Bu bağlamda gelişmiş ülkelerde ailelere ve bireylere resmi koruma sağlanırken, gelişmekte olan ülkelerin büyük bir kısmında sosyal koruma programları noksandır. Ayrıca sunucusu ve faydalanıcısının sosyal ilişkilerine dayanan aile yardımları ile 
oluşturulan sosyal yardımlar da yaygın olmamaktadır (Kapar,2003:53; Kasseeah ve Ragoobur, 2011:8384; Thandika,2016:3; Ouma, 2020: 817).

Sosyal korumayı sınır ötesi hareketlilik olarak değerlendirmek mümkündür. Bu durum sosyal korumanın uluslararası dinamiklerle olan ilişkisine işaret etmektedir. Ancak öncelikle ulusal dinamiklerle ilişkilidir. Bu doğrultuda sosyal korumanın aktörleri de önce ulusal mekanizmalardır. Ulusal mekanizmaların eksik kaldığı noktalarda da uluslararası mekanizmalar harekete geçmektedir (Hujo, 2013:31).

Ulusal düzeyde en etkili sosyal koruma aktörü devlettir. Devletin hukuki plan ve programlarının sonucunda yaptığı resmi yardımlar sosyal korumanın bir parçası olarak kabul edilmektedir. Her türlü ayrımc1lığa engel olmayı ve toplumsal yaşama aktif katılımı tüm insanlara sağlamakla yükümlü olan devletin, engellilere yönelik hukuksal araçlarının bir tezahürü olan politikaların da benzer kaygılar içerisinde olması gerekir. Ancak devletlerin kıt mali kaynak, dar kapsam, iş birliği eksikliği gibi çeşitli engellerle karşılaşacakları açıktır (Laskowska, 2018:71-76; Scully, 2010:26-30; Hujo, 2013:40).

Resmi yardımlar sunan devletin dışında ailenin rolü de önemlidir. Sosyal korumanın aktörü olması bağlamında ailenin bilinçlendirilmesi ve desteklenmesi, hem engelsiz yaşam için atılmış bir adım hem de engelli kişinin her anlamda iyi hissetmesine imkân sağlayabilecek bir güçtür (WHO, 2011:156).

Ancak farklı gerekçelere bağlı olarak bazı ailelerin olanakları sınırlıdır. Bu bağlamda eğitim öncelikli olmak üzere engelli bireyin tüm gereksinimlerini karşılayabilecek maddi gücü olmayan ailelerin başta devlet, sonra da vakıflar veya dernekler tarafından maddi açıdan desteklenmesi gerekir. $\mathrm{Bu}$ durumda eğitim alabilen ve koşulları iyileşen engelli sayısı devletlerin, vakıfların ve derneklerin gücü oranında artabilmektedir (Besiri, 2009:363).

Engelsizlik bağlamında çeşitli çalışmalar yürütülmektedir. Bazı ülkelerde "Special Educational Needs" (SEN) çalışmaları yürütülmektedir. Bu çalışmaların en önemli amaçlarından biri de engellilerin hayatta kalmalarını sağlayacak donanımı sağlamaktır. Erişilebilir korunaklı okullar, uyumlu ve özverili çalışanlar ile engellilerin eğitim düzeyinin arttırıldığ 1 iddia edilir. Hindistan' da SEN kapsamında olan yaklaşık 50 milyon çocuk olduğu tahmin edilmektedir. Özellikle çalışanların amaca binaen her an hazır olmaları ile SEN, Asya ve Pasifik bölgesinin merkezi politikası haline gelmiştir. Hindistan'da temel temizlik ve hijyen olanaklarının sınırlı olması da büyük engellerdendir. Hindistan hükümetinin yoksul bölgelere verdiği hibenin yetersiz olması nedeniyle yerel sivil toplum örgütü olan Mobility India ve İsviçre merkezli yardım kuruluşu olan "MIBLOU Switzerland" tarafından finanse edilen temel sıhhi hizmetler çerçevesinde engellilere yönelik tuvalet projesi gerçekleştirilmiştir. 50 tuvaletin inşa edilmesiyle engelsiz yaşama katk1 sunulmuştur (Peters, 2003:4; WHO, 2011:34- 37; ICF, 2001:17; World Report on Disability, 2011:13). 
Engelli nüfusun yüksek ve imkanların sınırlı olduğu Afrika kıtası engelsiz yaşama yönelik projelere gereksinim duymaktadır. "Disability- Inclusive Education in Africa" Programı 21. yüzyılda engelsiz yaşam adına umut verici en önemli çalışmalardandır. Çok sayıda engellinin bulunduğu Afrika kıtasına yönelik olan çalışmada cinsiyet ayrımı yapılmaksızın üç yıl boyunca engelli çocukların eğitiminin desteklenmesi amaçlanır. Modern içerikli ve kapsayıcı olduğu iddia edilen engelli eğitimi projesi, öncelikle Burkina Faso, Gana, Etiyopya, Malawi ve Güney Afrika'daki engellileri kapsama almayı planlamıştır (Famuyide- Hatch, 2018:19-34).

\section{Engellilere Yönelik Birleşmiş Milletler Çalışmaları}

Dünya nüfusu içerisindeki engelli sayısı azımsanmayacak kadar yüksektir ve yükselmeye devam etmektedir. BM Genel Sekteri Kofi Annan'ın 3 Aralık 1997 tarihinde engellilerin dünyanın en büyük azınlığı olduğunu belirtmesi ile konunun önemi anlaşılmaktadır. Farkındalık yaratma kaygısında olan BM, 1982 yılını “Engelliler Yılı” olarak belirlemiştir. Engelliler ile ilgili eyleme gereksinim duyulması nedeniyle de 10- 16 Mayıs arası "Engelliler Haftası" olarak belirlenmiştir. Belirlenmiş olan 3 Aralık tarihi de "Dünya Engelliler Günü" olarak farkındalığı artırma çabasına katkı sunmaktadır. 1945 sonrasının önemli belgeleri arasında kabul edilen ve devletleri sorumluluk almaya teşvik eden İnsan Hakları Evrensel Bildirgesinin 2, 3, 16, 22, 25 ve 26. maddeleri de engelliler konusunda sorumlulukları belirlemiştir (Çitil-Üçüncü, 2018:245; Öztürk- Sert, 2018:258; Çelik, 2016:223).

Hassasiyeti yüksek, kırılgan ve dezavantajlı grup içerisinde yer alan engelliler, genel olarak uluslararası örgütlerin insan hakları söylemlerinin merkezindedir (WHO, 2011:27). Çünkü insan haklarının korunması ve sürdürülebilir kalkınma hedefleri ile ilişkilendirilen engelsiz yaşam fikri, engelli ve engelsiz fark etmeksizin hiçbir insanın ayrımcı bir tutuma maruz kalmaması ile doğrudan bağlantılıdır. BM Genel Kurul raporlarında, İnsan Hakları Evrensel Beyannamesinde ve insan haklarını konu alan diğer belgelerde ayrımcılığı ortadan kaldırmak amaçlanır. İnsanın doğduğu andan itibaren birtakım hakları olduğu, bu haklara saygı duyulması gerektiği ve saygı duyulmaması halinde birilerinin ayrıcalıklarının artacağı ve diğer insanların haklarını kullanamayacağı açıktır. Ayrıca belgelerde genel olarak 1rk, dil din, cinsiyet, renk, ulusal ve sosyal köken, engellilik, ideoloji, politik ve diğer görüşler bakımından farklılıkların ayrımcılığa yol açmaması gerektiği vurgulanmaktadır (UN General Assembly Report, 2012:1; UN General Assembly Report, 2014:3).

Engelliler başta olmak üzere ekonomik ve sosyal durumlar karşısında hassas olan savunmasız insanlar için güvenilir, ulaşılabilir, uygun kalitede hizmet sunumu BM kalkınma hedeflerinin gündemindedir. BM Genel Kurul raporlarında kamu hizmetlerinin eşit dağıtılması gerektiği belirtilir. BM'nin önce Milenyum Hedefleri, daha sonra da 2030 hedefleri ile bağlantılı şekilde uzun süreli planları doğrultusunda öncelikle ihtiyaç sahiplerini doğru bir şekilde belirlemek ve daha sonra da zamanında hizmet sunabilmek amaçlanmıştır (UN General Assembly Report, 2015:5). 
BM, bir katalizör görevi görerek kurallar oluşturmaya çalışmaktadır. "United Nations Standard Rules on the Equalization of Opportunities for Persons with Disabilities" ile belirlenen kurallar, engellilerin toplumsal hayata daha fazla katılmasına yöneliktir. Eşit katılımı sağlamak amacıyla ana başlıklar altında toparlanan kuralların ilk başlığı eşit katılım için ön koşullardır. İkinci ana başlıkta eşit katılım için hedeflenmiş alanlar, üçüncü ana başlıkta uygulama önerileri ve dördüncü başlıkta izleme mekanizmasına ilişkin bilgiler yer alır. Bu başlıklar altında devletlerin yapması gerekenler belirlenmiştir. Bağlantılı olarak birçok ülkede düzenlemeler yapılmıştır. Yapılan düzenlemeler doğrultusunda toplumsal yaşamın izlerini taşıyan alternatif uygulamaların ortaya çıktığı ve kişiyi evinde gibi rahat hissetmesini sağlayan bakım evlerine dönüş yapıldığı; Norveç’te ve İsveç’te engelliler için olan kurumsal yerleşmelerin kaldırıldığı, Avustralya, Belçika, Almanya, Yunanistan, Hollanda, İspanya'da alternatif toplumsal yaşam düzenlemeleri ile kurumsal yapıların birlikte hizmet sunduğu görülmektedir (Independent Living Institute (ILI) 28.03.2021; WHO, 2011:137- 147).

BM'nin engellilere yönelik çalışmalarının holistik bir bakış açısı ile değerlendirilmesi için uzmanlık kuruluşlarının planları ve programları bilinmelidir. Eğitim Bilim ve Kültür Organizasyonu özel eğitimle ilgili planlar hazırlamak veya uygulamaya geçirmekle, DSÖ sağlık hizmetleri ile ilişkili teknik destek vermekle, BM Çocuk Fonu çocuklarla ilişkili planlar ve programlar hazırlamakla, Uluslararası Çalışma Örgütü iş piyasasına girişi kolaylaştırmak ve iş piyasasında ayrımcılığı önlemekle, Dünya Bankası da projelere mali katkı yapmakla ilgilenir. Ayrıca BM Genel Sekreterliği Ekonomik ve Sosyal İşler Bölümünün Sosyal Politika ve Kalkınma Birimi tarafından engellilere yönelik programlar yürütülür. Bu doğrultuda BM'nin neredeyse kurulduğu tarihten itibaren engellilere yönelik belgeleri ve etkinlikleri olduğu söylenebilir (Çitil- Üçüncü, 2018:243; World Bank Group, 2018:1).

BM'nin engellilerle ilişkili etkinliklerinin ve belgelerinin genel bir listesi aşağıdaki tabloda yer almaktadır. 
Tablo 1. Engellilere Yönelik Birleşmiş Milletler Düzenlemeleri

\begin{tabular}{|c|c|}
\hline DÜZENLEME & $\begin{array}{l}\text { DÜZENLEMENIN } \\
\text { YAPILDIĞI YIL }\end{array}$ \\
\hline "íNSAN HAKLARI EVRENSEL BİLDİRGESI" & 1948 \\
\hline “CENOVA DÜZENLEMESİ” & 1950 \\
\hline "BM, ILO, UNDP, WHO, UNESCO, UNICEF TOPLANTISI" & 1952 \\
\hline $\begin{array}{l}\text { "ENGELLİLERIN MESLEKİ REHABİLïTASYONU HAKKINDA } 99 \\
\text { SAYILI ULUSLARARASI ÇALIŞMA ÖRGÜTÜ TAVSIYE KARARI" }\end{array}$ & 1955 \\
\hline “ÇOCUK HAKLARI BİLDİRİİ” & 1959 \\
\hline $\begin{array}{l}\text { "EĞiTIMIME AYRIMCILIĞA KARŞI SÖZLEŞME UNESCO GENEL } \\
\text { KONFERANSI" }\end{array}$ & 1960 \\
\hline $\begin{array}{l}\text { "ZİHİNSEL ENGELLİ BİREYLERİN HAKLARI HAKKINDA } \\
\text { BİLDİRGESİ” }\end{array}$ & 1971 \\
\hline "BİRLEŞMISS MILLLETLER (SAKAT) ENGELLİ HAKLARI BİLDİRISİ" & 1975 \\
\hline “SUNDBERG BİLDİRGESİ"- Eğitim faaliyetleri & 1981 \\
\hline $\begin{array}{l}\text { “ENGELLİLERIN MESLEKİ REHABILİTASYONU VE İSTİHDAMI } \\
\text { HAKKINDA 159 SAYILI ULUSLARARASI ÇALIŞMA ÖRGÜTÜ } \\
\text { SÖZLEŞMESİ” }\end{array}$ & 1983 \\
\hline $\begin{array}{l}\text { "ENGELLİLERİN MESLEKİ REHABİLITASYONU VE İSTİHDAMI } \\
\text { HAKKINDA } 168 \text { SAYILI ULUSLARARASI ÇALIŞMA ÖRGÜTÜ } \\
\text { TAVSIYE KARARI” }\end{array}$ & 1988 \\
\hline "ÇOCUK HAKLARINA DAİR BİRLEŞMISS MİLLETLER SÖZLEŞMESİ” & 1989 \\
\hline “HERKES İÇIN EĞİTIM DÜNYA BİLDİRGESİ UNESCO” & 1990 \\
\hline \multicolumn{2}{|l|}{$\begin{array}{l}\text { "ENGELLILER ALANINDA İNSAN KAYNAKLARI GELIŞTIRME EYLEM PLANI IÇiN } \\
\text { TALLINN ÇERÇEVESII" }\end{array}$} \\
\hline $\begin{array}{l}\text { "ENGELLILEER (SAKATLAR) İÇIN FIRSAT EŞITLIIGGII KONUSUNDA } \\
\text { STANDART KURALLAR"- Eşit katılım için gerekli önlemleri, koşulları ve } \\
\text { hedef noktaları içermektedir. Rehabilitasyon amacı da vardır. }\end{array}$ & 1993 \\
\hline “SALAMANCA BİLDİRİSİ”- Özel eğitim ile ilişsilidir. & 1994 \\
\hline $\begin{array}{l}\text { "KOPENHAG SOSYAL KALKINMA BILLDİRGESI VE SOSYAL } \\
\text { KALKINMA EYLEM PLANI BM SOSYAL KALKINMA DÜNYA } \\
\text { KONFERANSI RAPORU” }\end{array}$ & 1995 \\
\hline "BİRLEŞMIŞ MILLETLER ENGELLİ HAKLARI SÖZLEŞMESI" & 2006 \\
\hline
\end{tabular}

Kaynak: (Çitil-Üçüncü, 2018: 244; T.C. Aile, Çalışma ve Sosyal Hizmetler Bakanlığı, Engelli ve Yaşlı Hizmetleri Genel Müdürlüğü Sitesi)

Dünya'da bir milyardan fazla insanın engelli olduğunu iddia eden DSÖ, 2014-2021 arasını kapsayan ve küresel eylem planını içeren bir rapor yayınlamıştır. Yayınlanan raporda çevresel bariyerlerin etkisi altında olan engellilerin yoksulluk içinde oldukları ve birçok imkândan yoksun kaldıkları belirtilmektedir. Tıbbi bakım, yardımcı cihazlar ve kişisel ihtiyaçlar daha fazla harcamayı gerektirmektedir ve engelli için yaşam maliyetini artırmaktadır. Gelişmekte olan 15 ülkede yapılan anket sonuçlarına göre, engelli kişilerin yaşadığı hanelerde sağlık için daha fazla bütçe ayrılmaktadır. Engelliliğin yaşı, kadın, çocuk ve diğer insanlar arasında orantısız bir şekilde arttığı belirtilmektedir ve bu anlamda sağlık hizmetlerinin artırılması gerektiği öne sürülmektedir (Çitil- Üçüncü, 2018:245; Gelmez, 2018:193; WHO, 2011:39; Zola 2005:20). 
Engelliler için en temel ihtiyaçlardan biri sağlik hizmetleridir. Çünkü herhangi bir afete veya tehlikeye maruz kalan engellinin sağlık masrafı, engeli olmayıp afet veya tehlikeye maruz kalan kişinin yaklaşık beş katı kadardır. Daha sonraki en temel ihtiyaç ise, güvenli bir yaşam alanıdır. Bu açıdan engellilerin korunmasına yönelik güvenlik tedbirleri önemli hale gelmektedir. Bu doğrultuda engelliler için erişilebilir ve ekonomik olarak uygun yolların, donanımlı kamu taşı1tarının, güvenli ve ulaşılabilir halka açık alanların olması gerektiği BM belgelerinde ifadesini bulmaktadır (UN,2015:12; UN, 2015:25).

Engelliliğin yoksulluğa neden olduğu veya yoksulluğun engelliliğe neden olduğu şeklinde engellilik ile yoksulluk arasında çift yönlü bir ilişkinin olduğu belirtilmektedir. Çift yönlü ilişkide yaşam maliyetinin artması ve kötü şartlarda yaşama ihtimali yüksektir (WHO, 2011:34). Uluslararası Çalışma Örgütü de engelliliğin maliyetli olduğu kanaatindedir. Engelli olan ve olmayan iki kişinin aynı gelire sahip olmasına karşın engelli olanın yaşamının maliyetli olması nedeniyle daha fakir olduğu vurgulanmaktadır (WHO, 2011: 39; Zola 2005: 20).

Ayrımcılığa maruz kalabilecek savunmasızlar kategorisinde değerlendirilen engellilerin güçlendirilmesinin en iyi yolu sürdürülebilir kalkınma hedefleri ile ilişkisi olan etkili ve şiddetten uzak eğitim ve öğrenimdir (UN General Assembly Report, 2015: 23). Birinci, ikinci ve üçüncü derecede eğitimin, yaşam boyu öğrenme imkânlarının, teknik ve mesleki eğitimin ulaşılabilir olması ile beceri düzeyinin arttırılacağı, topluma tam katılımın sağlanacağı ve firsatların önünün açılacağı öne sürülmektedir (UN General Assembly Report, 2015: 7).

UNESCO da özel eğitimin gerekliliğini belirtmektedir. Prensipleri ve uygulamaları ile hazırlanması öngörülen özel eğitimin hem devletlerin hem de uluslararası organizasyonların sorumluluğunda olduğu ifade edilmiştir. Özel eğitimin en önemli noktası da kaynaştırmayı ve sosyalleşmeyi mümkün kılmaktır. Eğitimin her aşamasında ve özellikle yüksek öğretimde kaynaştırma eğitimi için iş birliğinin artırılması ve bilgi ağının güçlendirilmesi gerektiği öne sürülürken, UNESCO'nun etkisi ile yapılan Özel Eğitim Dünya Konferansına katılan taraf devletlere rehber olabilecek öneriler sunulmuştur (Çitil-Üçüncü, 2018:246; GEM, 2014).

\section{Birleşmiş Milletlerin Engelsiz Yaşamı Sağlama Potansiyelinin Değerlendirilmesi}

BM, yarım asırdan fazla bir süredir birçok alanda faaliyet yürüterek, ekonomik ve sosyal statülerin değişiminde rol oynamaktadır. Bu minvalde en önemli belgelerinden biri olan "İnsan Hakları Evrensel Beyannamesinin" maddeleri tüm insanlar için hakları ve sorumlulukları belirtmektedir. Açıkçası, ya herkes için geçerli olan bir şeyi ya da hiçbir insanın yapmaması gereken bir şeyi belirten beyanname, akıl ve irade sahibi tüm insanların yapabilecekleri ve yapamayacakları konusunda eşit olduğuna ve sosyal bütünleşmenin önünde bir engelin olmadığına işaret etmektedir (İnsan Hakları Evrensel Beyannamesi (IHEB), 1948; Friedman, 2020:596). 
BM belgelerinin tamamı insan olmanın gerektirdiği hakları ve sorumlulukları ortaya koymaktadır. Bu minvalde BM sözleşmeleri, bildirileri ve faaliyetleri evrensel anlamda koruyuculuk misyonuna uygun olmaktadır. Ancak evrensel literatürde koruma misyonuna uygun olan belgeler, bir kitlenin kendine özgü durumunu detayları ile analiz etmiyorsa yetersiz kalmaktadır (Çelik, 2016: 242).

Farklı kitlelerin haklarını korumaya yönelik BM sözleşmeleri vardır. Ancak özel olarak belirli bir konu üzerinde olmayan sözleşmeler yetersiz kabul edilmektedir. Bu bağlamda kadınların, çocukların, göçmen işçilerin ve diğerlerinin haklarını koruyan sözleşmeler ile "İnsan Hakları Evrensel Beyannamesinin”, engelli hakları konusunda bağlayıcı olmadığı belirtilmektedir. Bu anlamda 2000 sonrasında oluşturulan “Engelli Hakları Sözleşmesinin” büyük bir açığı kapattığı öne sürülmektedir. BM Engelli Hakları Sözleşmesinin maddeleri de tam katılımı ve engelsiz yaşamı amaçlaması açısından önemlidir (Engellilerin Haklarına İlişkin Sözleşme (EHİS), 2006).

BM, engellilerin sosyal ve politik statüsünün değişiminde etkili olmak amacıyla engelsiz yaşamı sağlama çalışmalarına yön vermektedir. Ancak engeliler hakkında duyarlı olan BM'nin tüm engellilerin haklarına yönelik olan sözleşmesi 13 Aralık 2006 tarihinde A/RES/61/106 kararı ile kabul edilmiş, 30 Mart 2007'de imza ve onay için açılmış ve 3 Mayıs 2008 tarihinde yürürlüğe girebilmiştir. Bu belge tüm engellileri kapsaması ve ilgili yazında var olan eksikliği gidermesi adına önemlidir (Scully,2010:2627; UN Ekonomik ve Sosyal İşler Dairesi, Erişim Tarihi:28.03.2021).

BM belgelerinin belirli bir engelli gruba yönelik olması iyi niyetli de olsa bir ayrımcılığa işaret etmektedir. Bu durum engellilerle ilgili belgelerde de kendisini göstermiştir ve bu duruma sadece zihinsel engelli olanların haklarına yer verilen "Zihinsel Engelli Bireylerin Hakları Hakkındaki Bildirge" örnek verilmektedir. Bildirgede zihinsel engellilerin birtakım beceriler kazanmalarının neticesinde hayata tutunmalarını kolaylaştırmak planlanmaktadır. Ancak genel anlamda engelliler ile engelli olmayanlar arasındaki farklı durumlar eleştirilirken, sadece bir engel türüne yönelik düzenleme de eleştirilmektedir (T.C. Aile ve Çalışma Sosyal Hizmetler Bakanlığı Sitesi).

Engelliler ile ilişkili BM belgelerinin dili de önemlidir. Günümüzde geçerliliğini genel olarak yitirmiş olan medikal modele yakın bir dil kullanarak, engelli, sakat, özürlü gibi ifadelerle engelliler arasında ayrımcılığın altını çizen BM, paternalist bir tutum ile koruma vurgusu yapmıştır. Bu durumu 1970'li yıllardaki iki belge örneklendirmektedir. Bunlar ise, "1971 tarihli BM Akll Sakatlı̆g Olan Kişilere İlişkin ve 1975 tarihli Engelli Kişilerin Haklarına İlişkin Deklarasyon” olarak belirtilebilir (Çelik, 2016:227).

BM'nin paternalist dilinin etkisi ile hazırlananları tamamı uygulanmaya dönüştürülememektedir. Bu durum BM sözleşmelerini onaylayanların sorumsuzlukları ile alakalıdır. En başta BM belgelerini onaylayarak, engelsiz yaşamı sağlama çalışmalarına uyum göstereceklerini taahhüt etmiş devletler sözlerine sadık kalmamaktadır. Devletlerin mevzuatlarındaki eksiklik ya da 
uygulamalarındaki eksiklik taahhütlerine sadık kalamadıklarına kanıt oluştururken, BM'nin söylemlerini eylemlere yansıtamamasına neden olmaktadır (Dünya Engellilik Raporu, 2011: 113).

\section{SONUÇ}

Engellilik, medikal modele göre, temel bir sağlık sorunu olarak ifade edilmektedir ve işlevsellik ile ilişkilendirilmektedir. Modele göre, tedavi ile engelli bireyin işlevselliği kısmen azaltan veya tamamen yok eden durumunun ortadan kaldırılması amaçlanmaktadır. Sağlık sorununun giderilmesi ile engelli kişinin topluma uyum sağlamasının kolaylaşacağına inanılmaktadır. Çünkü medikal model, toplumun katı ve değişmez yapısını göz önünde tutarak, engelli kişinin değişimini öngörmektedir. Ancak engelliliğin farklı boyutları ile ilgilenmeksizin sadece tıbbi boyutunu göz önünde tutan medikal model, demode bir mantığın ürünü olarak önemini yitirmiştir. Günümüzde engelliliğin farklı boyutları göz önünde tutulmaktadır.

Engellilik ve engellilikle bağlantılı konular, son zamanlarda terminolojide önemli yer edinen sosyal modele göre tanımlanmaktadır ve açıklanmaktadır. Engellilik, işlevsellikten daha fazla fiziksel ve sosyal çevrenin sebep olduğu durumlarla ilişkilendirilmektedir. İşlevsel yetersizliğin göz önünde tutulmaması, toplumun empati yeteneğinden yoksun olması ve toplumun önyargıları ile meydana gelen engeller göstermektedir ki, engelleri yaratan veya engellerin yaratılmasına neden olan toplumdur. $\mathrm{Bu}$ durumda sosyal model, asıl değişmesi gerekenin toplum olduğu gerçeğini savunmaktadır. Açıkça belirtmek gerekirse, engelsiz yaşamın sağlanmasına ve erişilebilirliğin artırılmasına en uygun modelin de sosyal model olduğu düşünülmektedir.

Diğer taraftan hak temelli model de sosyal modelin bir bağlantısı olarak kabul görmektedir. İnsan hakları bağlamında tüm insanların doğuştan gelen haklara sahip olduğu, sahip olunan hakların korunması gerektiği öne sürülerek, engelli bireyin de hak sahibi olduğu belirtilmektedir. Açıkça ifade etmek gerekirse, engelli bireylerin haklarının önemsenmesi de ihtiyaç odaklı yaklaşımdan hak odaklı yaklaşıma geçilmesinin neticesidir.

Farklı nedenlerden ötürü engelli sayısı artmaktadır. 28.03.2021 tarihinde kontrol edilen DSÖ’nün sitesinde de dünya üzerinde 1 milyardan fazla insanın ve neredeyse dünya nüfusunun \%15'inin bir tür engele sahip olduğu yer almaktadır. Bu bağlamda da çevresel bariyerler ve diğer engeller dikkat çekmektedir. Doğal olarak diğer yaşam alanları ile birlikte asgari yaşam alanını tehdit eden faktörlere ve bu faktörlerin ortadan kaldırılmasına odaklanmak gerekmektedir.

Engelliler yaşamın devamlılığını tehdit eden risklerle karşı karşıyadır. Engelliler, engelli olmayanlara göre daha kötü şartlarda yaşamaktadır, yoksulluk ile karşılaşmaktadır, eğitim alamamaktadır veya kısmen almaktadır. Hiçbir ayrıma maruz kalmaksızın sağlık hizmetlerinden yararlanamayan engelliler, önyargıların hedefinde yer almaktadır ve psikolojik olarak kötü durumdadır. 
$\mathrm{Bu}$ durumda önemli olan da engelli hayatını kolaylaştırmaktır. Açıkça ifade etmek gerekirse, doğan ve yaşamını devam ettiren her bireyin yaşamın tüm alanlarına katılabilmesi gerekmektedir. $\mathrm{Bu}$ mantık doğrultusunda yaşam alanlarının çevresel bariyerlerden arındırılması fikri kaynaştırma mantığına da uygundur. Bu durumda ilk sırada düşünülmesi gereken de engellilerin bugünü ve geleceğidir. Engellilerin güvende olması için geleceğe yönelik beceri kazandıran bir öğrenme ortamı gerekmektedir. Bilgi ve beceri kazanmanın en iyi yolunun eğitim olduğu bilinciyle eğitim için gerekli araç ve gereç eksiksiz olmalıdır. Bu durumda eğitim ile vasıf kazanabilen engellilerin istihdamda yer edinmesi kolaylaşacaktır. İstihdamda yer edinmekle gelir başta olmak üzere diğer kazançları elde edebilen engellilerin özgüvenleri de artacaktır.

Engellilerin psikolojik durumlarının düşünülmesi de önemlidir. Açıkçası, engellilerin kötü muamelelere maruz kalması ile psikolojik çöküntü yaşaması arasında doğru yönlü ilişki bulunmaktadır. Psikolojik çöküntünün etkisi de intihara eğilimi artırmaktadır. Bu amaçla engellilerin yaşam alanları içerisinde s1k s1k kontrol edilmesi ve değerli olduklarının hissettirilmesi gerekmektedir.

Bir otoritenin düzen kaygısıyla ortaya koyduğu sözleşmeler ve anlaşmalar da dezavantajlı durumda olanlar ile olmayanlar arasındaki eşitsizliklerin giderilmesi açısından önemlidir. Bu doğrultuda BM belgeleri de engellilere yönelik eşitlik çerçevesinde şiddet içermeyen, kapsayıcı, etkili, güvenli durumlar ve ortamlar yaratmak amacındadır. Bu yönde genel anlamda insan hakları çerçevesinde değerlendirilen belgeler ile tüm engellileri göz önünde tutan "BM Engelli Hakları Sözleşmesi" anlamlidir.

Uluslararası alanda bir standart oluşturma gayesinin ürünü olan "BM Engelli Hakları Sözleşmesi”, engellilerin durumunu göz önünde bulundurarak öneriler sunmaktadır ve onaylayan devletlere sorumluluk yüklemektedir. Açıkça ifade edilmemiş olsa da BM'nin önerilerini yapacak, engellilere destek sunacak ve engelliler için gerekli tedbirleri alacak olan öncelikle devletler sonra da yerel yönetimlerdir. Devletin bütçe ayırması, modern yöntemleri kullanması, ilişkili örgütler ile iş birliği yapması, mevzuatı düzenlemesi, mevzuatta olanları uygulaması gerekmektedir. Yerel yönetimlerin de engelli hizmet birimlerini kurması, sağlık hizmeti sunması ve engellilere yönelik sosyal yardım yapması önemli olsa da daha önemli olanı yaşam alanlarının kullanışlı hale getirilmesidir. Çünkü engellinin erişilebilirliğinde etkisi olan sokaklarda park edilen araçlar genel olarak engelli yolunu kapatmaktadır. Kaldırımların farklı amaçlar için kullanılması ile engellilere geçiş alanı kalmamaktadır ve bazı binaların fiziksel yapısı nedeniyle giriş ve çıkış kolay olmamaktadır. Sonuçta engelsiz yaşamla ilişkili düzenlemelerin uygulanmaması ve sürdürülebilir olmamas1 nedeniyle sorunlar tamamen yok olmamaktadır. Var olan eksiklikler yüzünden engelsiz yaşama erişimle alakalı tartışmalar son bulmamaktadir.

Sonuçta BM, uluslararası arenada standartlar belirleme kaygısında olan bir yapıdır. Bu bağlamda farklı alanlarda birçok sorun ile ilişkili durum analizi yapmaktadır, duruma göre tavsiyeler sunmaktadır 
ve eylem çağrısında bulunmaktadır. BM, engellilerin hem rehabilitasyonunu hem de habilitasyonunu önemsiyor olsa da engeller ile karşılaşmaktadır. En dikkat çekici engel de taraf ülkelerin engellilerle ilişkili tutumlarıdır. BM söylemlerinin içeriğini oluşturan yazılı belgeleri onaylayan ülkeler ilgili yazılı belgeye uygun faaliyetleri yapmak üzere sorumluluk almaktadır. Ancak birtakım gerekçeler öne süren devletler, engellilere yönelik faaliyetleri ya yapmamaktadır ya da kısmen yapmaktadır. Bu durumda BM belgelerine taraf olan devletlerin iç yapısı önemlidir. Çünkü her durumda taraf devletlerin ekonomiksosyal ve siyasal durumunun yanısıra mevzuatları, diğer düzenlemeleri ve uygulanmaya açık programları belirleyicidir. Sonunda erişilebilir ve engelsiz olma özelliklerine sahip yaşam alanları fikrinin uzun vadeye ihtiyacı vardır.

Diğer taraftan da bariyersiz bir yaşam için engelli olmayanlar da bilinçlendirilmelidir. En başta ise, engelli olmayanlara engellilerin yaşam alanlarını sınırlandırmama eğitiminin verilmesinin neticesinde farkındalık artırılabilir ve bilinç düzeyi yükseltilebilir. Çünkü kurumsal yapıların yerini toplumsal hayata katılımı artıran düzenlemelerin almasıyla engellinin bakımını üstlenen aile üyeleri ile birlikte toplumun diğer fertleri de aynı şekilde bilinçlendirilebilecek ve bağlantılı olarak empati düzeyi yükseltilebilecektir.

\section{KAYNAKÇA}

Azarkan, Ezeli ve Benzer, Ekrem. (2018). "Birleşmiş Milletlerin Engelli Kişilerin Haklarına Dair Sözleşme ve Türkiye'de Engelli Hakları”. DÜHFD 23/38, 3-29.

Barnes, Colin- Mercer, Geof. (2005). "Disability Work and Welfare: Challenging the Social Exclusion of Disabled People". Work, Employment and Society 19/3, 527-545.

Besiri, Arzu. (2009). "Yoksulluk Ekseninde Engellilerin Eğitimi”. TBB Dergisi 83, 353-374. m2009-83-536 (barobirlik.org.tr) Erişim Tarihi: 21.02.2019.

Bricout, John. C., Porterfield Shirley L., Tracey, Colleen M., Howard, Matthew O. (2004). "Linking Models of Disability for Children with Developmental Disabilities". Journal Social Work in Disability \& Rehabilitation 3/4.

Brzuzy, Stephanie. (1999). "Nothing About Us With out Us: Disability, Oppression and Empowerment”, The Journal of Sociology\& Social Welfare 26 /1, 191-194.

Brkic, Miroslav., Jugovic, Aleksandar., Glumbic. Nenad. (2012). "Residential Care for Children with Intellectual Disabilities in The Social Protection System in Serbia". European Journal of Social Work 17/2, 237-251.

Çelik, Elif. (2016). "Onuncu Yılında Birleşmiş Milletler Engelli Kişilerin İnsan Hakları Sözleşmesi ve Sözleşme Ruhu”. İnönü Üniversitesi Hukuk Fakültesi Dergisi 7/1, 219-246.

Çitil, Mahmut - Üçüncü, Muhammet Kürşat. (2018). "Türkiye'de Engelli Hakları ve Engelliler Hukukunun Durumu”, Türkiye Adalet Akademisi Dergisi 35, 233-278. 
DAWN CANADA (Disabled Women's Network of Canada) Erişim Tarihi: 24.03.2021 https://www.dawncanada.net/about/about/

Dünya Engellilik Raporu, 2011, T.C. Aile Sosyal Politikalar Bakanlığı, Anıl Group Matbaa, Erişim Tarihi:12.03.2021 diwnu3i5.pdf (ohu.edu.tr).

Edwards, Claire. (2001). "Inclusion in Regeneration: A Place for Disabled People?". Urban Studies 38/2, 267-286.

Engellilerin Haklarına İlişkin Sözleşme (CRPD). (2006). Birleşmiş Milletler, Erişim Tarihi: 28.03.2021. https://www.un.org/development/desa/disabilities/convention-on-the-rights-of-persons-withdisabilities.html.

Famuyide, Aji- Rachel Hatch. (2018). Disability Responsive Inclusive Education Policy and Systems Mapping. Education Equity Initiative. https://www.slideshare.net/DrNICHCY/disabilityresponsive-inclusive-education-policy-andsystems-mapping-91942881?qid=165b5bc8-5eb7-4177-b8f2-

$471401 \mathrm{a} 7332 \mathrm{~b} \& \mathrm{v}=\& \mathrm{~b}=\&$ from_search $=1$

Filmer, Deon. (2008). "Disability, Poverty and Schooling in Developing Countries: Results from 14 Household Survey". The World Bank Economic Review 22/1 (2008),141-163.

Friedman, Carli (2020). "The Relationship Between Disability Prejudice and Disability Employment Rates". Work 60, 591-598.

Gelmez, Özateş-Özge Sanem. (2018). "Engelliliğe İlişkin Varsayımların Keşfi: Görmezden Gelme Ya da Normal Dışı Görme”, Avrasya Sosyal ve Ekonomi Araştırmaları Dergisi 5 /5, 192-200.

Genç, Yusuf- Çat, Güldane. (2013). "Engellilerin İstihdamı ve Sosyal İçerme İlişkisi”. Akademik İncelemeler Dergisi 8/1, 363-393.

GEM (2014). Global Education Monitoring Report.GAW2014-Facts-Figures-gmr_0.pdf.pdf (unesco.org)

Gorz, Andre. (1999). Reclaiming Work Beyond the Wage-Based Society. çev. Chris Turner. Malden USA: Published by Polity Press in Association with Blackwell Publishers Ltd.

Habib, Lina Abu. (1995). "Women and Disability Don't Mix Double Discrimination and Disabled Women's Rights", Gender and Development 3/2, 49-53.

Hughes, Karen vd. (2012). "Prevalence and Risk of Violence Against Adults with Disabilities: A Systematic Review and Meta-Analysis of Observational Studies". The Lancet 379/9826, 1621-1929.

Haveman, Robert- Wolfe Barbara. (1990). "Well-Being of the Disabled: 1962- 1984”. The Journal of Human Resources $25 / 1,32-54$.

Hujo, Katja. (2013). "Linking Social Policy, Migration and Development in a Regional Context: The Case of Sub Saharan Africa". Regions \& Cohesion 3/3, 30-55.

ICF / International Classification of Functioning Disability and Health. (2001). Geneva: WHO LibraryCataloguing-in-Publication,29.03.2021. https://apps.who.int/iris/bitstream/handle/10665/42407/9241545429.pdf?sequence=1\&isAllowed=y

ILI / Independent Living Institute. "Bağımsız Yaşam". Erişim Tarihi: 28.03.2021. https://www.independentliving.org/indexen.html 
İHEB, İnsan Hakları Evrensel Beyannamesi. (1948). United Nations. Erişim Tarihi: 28.03.2021. https://www.un.org/en/about-us/universal-declaration-of-human-rights

Kapar, Recep. (2003). “Sosyal Korumanın Yaygınlaștırılması”. Dokuz Eylül Üniversitesi Sosyal Bilimler Enstitüsü Dergisi 5/4, 49-69.

Kara, Bülent. (2016). “Türkiye'de Engelli Bireylerin Yasal Hakları ve Uygulamadaki Yeri”. International Journal of Social Science 48, 249-260.

Kasseeah, H., Ragoobur, V.T. (2011). Assessing The Formal Social Protection System in Mauritius, The International Journal's Research Journal of Social Science \& Management, 01(06),82-94.

Laskowska, Katarzyna. (2018). "Social and Legal Situation of Handicapped Persons in the Russian Federation”, Bialostokie Studia Prawcizne 23/4, 67-76.

LEE, Ronald. (2003). "The Demographic Transition: Three Centuries of Fundamental Change”. Journal of Economic Perspectives 17 /4.

Malecki, Christine K. (2020). "Disability, Poverty and Other Risk Factors Associated with Involvement in Bullying Behaviors". Journal of School Psychology 78, 115-132. https://doi.org/10.1016/j.jsp.2020.01.002

Neufeldt, Aldred H. (1995). "Empirical Dimensions of Discrimination against Disabled People”. Health and Human Rights 1/2, 174-189.

Oliver, Mike -Barnes Colin. (2010). "Disability Studies, Disabled Peoples and Struggle for Inclusion". British Journal of Sociology of Education 31/5, 547-560.

Ouma, M. (2020). "Accounting for Choices and Consequences: Examining the Political Economy of Social Policy in Africa", S. O. Oloruntoba, T. Falola (eds.), The Palgrave Handbook of African Political Economy, Palgrave Handbooks in IPE, https://doi.org/10.1007/978-3-030-38922-2_44.

Öztürk, Yüksel -Sert, Ayşe Nevin. (2018). "Engelliler ve Seyahat”. Çok Disiplinli Çalışmalar. ed. Bilgehan Gülcan- Güler Sağlam Arı. 248-266. Ankara: Detay Yayıncılık.

Peters, Susan J. (2003). Inclusive Education: Achieving Education for all by Inclusion Those With Disabilities and Special Education Needs. The World Bank. http://citeseerx.ist.psu.edu/viewdoc/download?doi=10.1.1.1017.3887\&rep=rep1\&type=pdf

Powell, Jackie- Lovelock, Robin. (1997). "Disabled People's Involvement in a European Programme", The British Journal of Social Work 27 / 4 Special Issue: Oppression and Empowerment, 565-583.

Sendi, Richard- Kefo Kerbler Boštjan. (2009). "Disabled People and Accessibility: How Successful is Slovenia in the Elimination and Prevention of Built-Environment and Communication Barriers?" Urbani Izziv 20 /1, 123-140.

Scully, Jackie Leach (2010). "Hidden Labor: Disabled / Nondisabled Encounters, Agency and Autonomy". International Journal of Feminist Approaches to Bioethics 3/2, 25-42.

Soriano, J.M., Molto, J.C., Manes J. (2003). "Improvement of Accessibility for the Disabled in University Restaurants”. Le Travail Humain 66 /4, 391-396.

Tellioğlu, Salih. (2019). “Avrupa Birliği ve Bazı Gelişmiş Ülkelerin Engellilere Yönelik Sosyal Politikaları ve Sosyal Hizmetleri”. Akademik Sosyal Araştırmalar Dergisi 34, 166-182. 
T.C. Aile Çalışma ve Sosyal Hizmetler Bakanlığı / T.C. AÇSHB. "Engelli ve Yaşlı Hizmetleri Genel Müdürlüğü”. Erişim Tarihi: 12.03.2021. Engelli ve Yaşlı Hizmetleri Genel Müdürlüğü | 1.2- Engelliler Konusunda Uluslararası Dokümanlar (ailevecalisma.gov.tr)

Thandika, M. (2016). Colonial legacies and social welfare regimes in Africa: An empirical exercise, UNRISD Working Paper, No. 2016-4, United Nations Research Institute for Social Development (UNRISD), Geneva, 1-26.

Titchkosky, Tanya. (2000). "Disabilities Studies: The Old and the New". The Canadian Journal of Sociology 25/2, 197-224.

UN / United Nations. (2012). General Assembly Report Resolution. Geneva: General Assembly.

UN / United Nations. (2014). General Assembly Report Resolution. Geneva: General Assembly 2014.

UN / United Nations. (2015). General Assembly Report Resolution. Geneva: General Assembly 17 Agust.

UN / United Nations. (2015). General Assembly Report Resolution. Geneva: General Assembly 21 October.

UN / United Nations. (2007). United Nations Report of World Economic Situation Prospects. New York. 1201.

UN/ United Nations. (2019). Disability and Development Report. New York. 1-340.

UN/ United Nations. "Department of Economic and Social Affairs Disability". Erişim Tarihi: 28.03.2021. https://www.un.org/development/desa/disabilities/convention-on-the-rights-of-persons-withdisabilities/the-10th-anniversary-of-the-adoption-of-convention-on-the-rights-of-persons-withdisabilities-crpd-crpd-10.html\#aroundtheworld

UNDP. (2021). “Engelliliği Kapsayan Gelişim”. 13.04.2021. Disability inclusive development | UNDP

WHO/World Health Organization. (2004). The Global Burden of Disease 2004 Update. Geneva: WHO LibraryCataloguing-in-Publication Data. https://www.who.int/healthinfo/global_burden_disease/GBD_report_2004update_full.pdf?ua=1

WHO/World Health Organization. (2011). World Report on Disability. Geneva: World Health Organization. https://www.who.int/teams/noncommunicable-diseases/sensory-functions-disability-andrehabilitation/world-report-on-disability

WBG/ World Bank Group. (2018). Disability Inclusion and Accountability Framework. Washington: World Bank.

ZOLA, Irving Kenneth. (2005). "Toward the Necessary Universalizing of a Disability Policy". The Milbank Quarterly 83 /4, 1-27.https://doi.org/10.1111/j.1468-0009.2005.00436.x

NVI Year In Review 2018. "WHO Department for Management of Noncommunicable Diseases, Disability, Violence and Injury Prevention". Erişim Tarihi: 17.02.2021 https://spark.adobe.com/page/V1r72p8UZc6dy/).

United Nations Disability Statistics Database /DISTAT. "United Nations Statistics Division". Erişim Tarihi: 23.03.2021 (https://unstats.un.org/unsd/demographic/sconcerns/disability/disab2.asp) 